- When Worlds Combine: How technologists and librarians communicate. The two languages and two cultures of librarianship and information technology.

- Making Connections: National Issues and Local Initiatives in Networked Information Resources. A survey and report on what's happening in the networked information and information resource field in the national organizations (e.g., ACRL, CAUSE, Internet Engineering Task Force [IETF], etc.), or in national communications of shared interests (e.g., some of the informal information communities that communicate on the Internet). Also a report on what's happening, at Indiana University and in the state of Indiana, that corresponds to national issues or addresses national initiatives.

- A report on the development and future plans of Indiana University's Library Electronic Text Resource Service (LETRS), a collaborative project between the University Computing Services and the Libraries to develop an innovative electronic text center.

Other INforum programs planned for the spring 1994 semester will address such topics as: "Information Anarchy and Information Overload;" "Copyright, Intellectual Property and Electronic Information;" and "Issues on the Internet and NREN."

\title{
Letters
}

\section{National Library Week fest}

\section{To the Editor:}

Susan Hahn and I chaired the committee for NLW [National Library Week] here at W.B. Roberts Library. We had a very limited budget so we used some of the resources at hand, our faculty and our music department. We had a fine free wcek of course! We also planned three major activities. An open house Sunday afternoon with music students singing show tunes and food prepared by the NLW committee. The next event was a poetry reading by six faculty members. This was very well attended; in fact the room we had it in was too small and we had to turn people away. The last event was jazz on the library lawn. The school jazz bands played for lunch hour. We invited people to come with a sack lunch. We followed the national theme of "Libraries Change Lives" and we added a sub theme "We Bring You the Arts." Events were well received and we plan to repeat them next NLW. I enjoy your short, practical pieces of news and your articles. I can always find something useful in CERL News.Victoria S. Chase, circulation librarian, Delta State University, Cleveland, MS

\section{Thanks from a 1993 award winner}

To the Editor:

I am writing to the editor to express my utmost appreciation for the wonderful hospitality I experienced from the ACRL BI section after receiving the Miriam Dudley Bibliographic Instruction Librarian of the Year Award. I would like to thank the committee, particularly its chair, Mary Ellen Litzinger, for selecting me to receive the award in 1993. Likewise I would like to publicly state my appreciation for the many letters of congratulations and good wishes I received from friends and colleagues who are members of ACRL. It was indeed an honor to receive this award, and I will treasure it forever.

I hope that this award will inspire new librarians to select bibliographic instruction/information literacy as one of their specializations to gain the necessary skills and experience for future academic library leadership. I know that working in bibliographic instruction is one of the best ways to gain experience in using creativity and talent in the right combination to address the changes that must be faced and to prepare for and succeed in the next century.

Again, I want to express my sincere thank you for this great honor that ACRL and the BI section bestowed upon me.-Hannelore $B$. Rader, director, University Library, Cleveland State University

\section{Correction}

To the Editor:

The list of instructors contributing to the Electronic Library course (CERL News, July/August 1993, p. 380) at the University of Oregon should have included Isabel Stirling, head of the Science Library. Stirling taught access to the Internet through gophers and contributed to the planning of the course--Paul Frantz, coordinator of library instruction, University of Oregon, Eugene 